\title{
Influence of thawing and cooking methods on quality of libyan camel meat
}

\author{
*Elneairy, N.A, Elgerbi, A.M.** and Aboshenaf, F.** \\ *Food Sci.\&Tech. Dept.Faci.of Agric;ALFayoum Univ. Egypt \\ **Food Technology Dept. Fac. Engineering and Tech., Sebha Univ., Libya
}

\begin{abstract}
The effect of thawing and cooking methods on chemical composition and quality attributes of Libyan camel meat was investigated. The camel meat was prepared then packaged and frozen at $-28^{\circ} \mathrm{C}$ for 20 days. Chemical composition, microbiological examination and sensory evaluation were conducted on samples thawed and cooked samples by different methods. The percent of loss drip ranged from 1.02 to $22.95 \%$, thawed sample in running water had the highest value meanwhile, thawed sample in microwave had the lowest value. Thawing and cooking decrease water holding capacity (WHC) of camel meat. Thawing decreased ash content of camel meat while thawing decreased proteins content in all samples except sample thawed in microwave. Microwave thawing and cooking decreased loss of proteins and minerals meanwhile, proteins and minerals moved from meat to soup during wet cooking (Blanching). The total bacterial count, coliform group were very low for sample thawed in microwave and refrigerator methods in comparison with that thawed at room temperature and running water. The staphylococcus was $6.5 \times 10^{2}$ and $1.1 \times 10^{3}$ for thawed samples by refrigerator and microwave thawing, respectively. Meanwhile, it was $3.3 \times 10^{4}$ for sample thawed at room temperature. Cooking under pressure enhanced WHC, texture and juiciness of meat from aged camel. Cooking loss ranged from 26.25 to $34.12 \%$. Thawed sample by microwave then cooked under pressure had the lower cooking loss. The best quality of camel meat was observed for thawed sample in microwave then cooked in pan under pressure followed by thawed sample in refrigerator and cooked in pan under pressure.
\end{abstract}

Keywords: Libyan camel meat, Thawing, cooking, Chemical composition, Total bacterial count, Sensory evaluation.

\section{Introduction}

The practice of freezing meat to prolong its shelf-life has been practised for thousands of years. Freezing plays an essential role in this industry in ensuring the safety of meat and meat products. Nonetheless, the consequences of freezing and thawing on chemical composition and quality of meat remaining significant problem (Leygoine et al., 2012).

The main problem faces production of camel meat its toughness. This toughness due to high percent of connective tissues in camel meat specially in camels more than 4 years old (Sheriha, 2000).

There is general agreement in the literature that the tenderness of meat increase with freezing and thawing when measured with peak force (Patsias et. al. 2008).

The US Food and Drug Administration Food Code (2005).recommends several thawing methods for raw meat products: thawing under refrigeration $\left(\leq 5^{\circ} \mathrm{C}\right)$, thawing submerged under running water $\left(\leq 21^{\circ} \mathrm{C}\right)$ and thawing as a part of cooking process in the case of microwave thawing (Shrestha et al., 2009).

In Libya there is another thawing method in house by thawing at room temperature $\left(22-25^{\circ} \mathrm{C}\right)$. Each of the above thawing methods presents some disadvantages to food service operation (Shrestha et al. 2009).

The quality of cooked meat depends on the temperature, time and pressure during cooking (Sheriha, 2000).
In this study we try to increase the tenderness of camel meat by freezing and thawing, using different method also define the best method for thawing and cooking camel meat.

\section{Materials and methods}

Materials:

Camel meat: Camel meat was obtained from local market in south of Libya

\section{Methods:}

\section{Sample preparation:}

Samples were prepared by removing bone, then cuts to pieces equal in weight and shape. The prepared meat was packaged in polyethylene bags (each package contained $200 \mathrm{~g}$ ), then stored at ($28^{\circ} \mathrm{C}$ ) for 20 days.

\section{Thawing:}

The freeze samples were thawed according to the following methods:

Thawing at $6 \pm 1^{\circ} \mathrm{C}$ was done in refrigerator for 12 hrs.

Thawing at room temperature $\left(24 \pm 2^{\circ} \mathrm{C}\right)$ was done at room temperature for $8 \mathrm{hrs}$.

Microwave thawing was done at 160 watt by using $100 \mathrm{~g}$ meat for $3 \mathrm{~min}$.

Running water thawing was done by submerging the package under running water for $3 \mathrm{hrs}$. 
- Running water thawing without package was done by submerging the meat pieces under running water for $3 \mathrm{hrs}$.

\section{Cooking:}

The meat samples were cooked according to the following methods:

- Microwave cooking was done by $100 \mathrm{~g}$ meat at 480 watt for 8 min.

- Wet cooking was done by $100 \mathrm{~g}$ meat in 1000 $\mathrm{cm}^{3}$ of water for $2 \mathrm{hrs}$. Under normal air pressure.

- Wet cooking under pressure was done on $100 \mathrm{~g}$ in $1000 \mathrm{~cm}^{3}$ water with using autoclaved pan for $1 \mathrm{hr}$.

\section{Chemical analysis:}

Moisture content, soluble and insoluble ash in water, crude protein, crude fat content, $\mathrm{pH}$ and WHC were determined according to A.O.A.C (2005).

\section{Microbiological examination:}

Microbiological examinations were done for fresh and thawed meats: total viable bacteria counts, coliform group, staphylococcus bacteria and yeast and molds were enumerated according to the methods established by (APHA, 1992).

\section{Sensory evaluation (organoleptic evaluation):}

Texture, flavor, juiciness, color and appearance were evaluated. Every item given the following mark: flavor (25), texture (25), color (20), juiciness (20) and appearance (10).

\section{Statistical analysis:}

Table 1. Effect of thawing methods on chemical composition and physiochemical characteristics of Libyan camel meat.

\begin{tabular}{lcccccc}
\hline & & \multicolumn{4}{c}{ Thawing methods } \\
\cline { 2 - 7 } Component & $\begin{array}{c}\text { Fresh } \\
\text { meat }\end{array}$ & $\begin{array}{c}\text { Refrigerator } \\
7^{\circ} \mathrm{C} \\
\text { (For 12 } \\
\text { hrs.) }\end{array}$ & $\begin{array}{c}\text { Room } \\
\text { temperature } \\
\text { (For 8 hrs.) }\end{array}$ & $\begin{array}{c}\text { Microwave } \\
160 \text { Watt } \\
\text { (For 3 min) }\end{array}$ & $\begin{array}{c}\text { Running water } \\
\text { with package at } \\
\text { room } \\
\text { temperature } \\
\text { (For 3 hrs.) }\end{array}$ & $\begin{array}{c}\text { Running water } \\
\text { without package } \\
\text { at room } \\
\text { temperature } \\
\text { (For 3 hrs.) }\end{array}$ \\
\hline Moisture \% & 69.31 & 67.18 & 67.25 & 67.34 & 75.76 & 74.35 \\
\hline Proteins \% & 19.25 & 18.95 & 18.37 & 20.12 & 15.75 & 14.87 \\
\hline Crude fat \% & 9.81 & 9.68 & 7.90 & 9.69 & 9.09 & 7.79 \\
\hline Soluble ash \% & 1.01 & 0.79 & 0.87 & 0.75 & 0.55 & 0.66 \\
\hline Insoluble ash \% & 0.08 & 0.17 & 0.12 & 0.22 & 0.23 & 0.16 \\
\hline $\begin{array}{l}\text { T.V.N (mg/100 } \\
\text { g)* }\end{array}$ & 12.60 & 11.9 & 12.6 & 12.2 & 12.7 & 12.6 \\
\hline WHC \%** & 75.88 & 73.55 & 68.37 & 65.69 & 71.01 & 72.00 \\
\hline Drip \% & - & 2.09 & 2.14 & 1.02 & 22.95 & - \\
\hline PH & 5.70 & 5.7 & 5.2 & 5.8 & 5.9 & 5.8 \\
\hline
\end{tabular}

* T.V.N: Total volatile nitrogen $(\mathrm{mg} / 100 \mathrm{~g})$.

** W.H.C: Water holding capacity.

Effect of thawing methods on chemical composition of Libyan camel meat:

Data in (Table 1) indicated that, the moisture content for thawed samples at refrigerator, room temperature and microwave methods was decreased,
Statistical analysis was determined according to Sendecor and Cocharn (1980).

\section{Results and discussion}

\section{Chemical composition:}

Data in Table (1) indicated that the moisture content of Libyan camel meat was $69.31 \%$. The moisture content lower than moisture content of camel is lower than from other Arab countries. Babiker and Yousif (1990) found that the moisture content in Sudan camel meat is $75.89 \%$. The low moisture in Libyan camel meat indicate that camel meat from aged camel where, moisture content decreases with increase age and weight of camel (Abdallah, 1999 and Dawood and Alkanhal, 1995). The results of crude protein are in excellent agreement with those stated by El-Faer et al. (1991). Total crude lipid in Libyan camel meat was higher than which reported in literature and this indicate that the camel was aged. Crude lipids increase with increasing the age of camels (Abdallah, 1999). On the other hand, the value of $\mathrm{pH}$ is in excellent agreement of those Babiker and Yousif 1990. The total volatile nitrogen was $12.60 \mathrm{mg} / 10 \mathrm{~g}$ meat, these results were low. $\mathrm{pH}$ and total volatile nitrogen indicated that the meat was fresh. The percentage of soluble and insoluble ash in water were 1.09, 1.01 and $0.08 \%$, respectively. These results are in a good agreement with those reported by Sheriha, 2000 and Abdallah (1999). Finally, the results indicated that WHC for Libyan camel meat was $75.88 \%$. 
freezing steric effects due to shrinkage of myofibrils cause moisture loss in frozen thawed meat. On the other hand, the moisture of samples thawed in running water with package or without package were increased due to absorb water from running water. Total volatile nitrogen (TVN) for sample which thawed in refrigerator and microwave is lower than other samples, this may be due to the low temperature in refrigerator was inhibit growth of microorganisms which increase TVN in the same time the time for thawing in microwave was very low (3 $\mathrm{min}$ ) and there is no enough time to growth microorganisms which cause increase in TVN. The soluble ash in water decreased in all samples. The crude protein decreased in all samples except microwave thawed sample. The lowest content of these components were in sample thawed in running water, this is may be due to high loss of drip. These results were in good agreement with those reported by Pham (2004) who reported that the moisture lost during thawing is rich in proteins, vitamins and minerals. There is no clear effect of thawing methods on total crude fat content of sample.

\section{Effect of thawing methods on physiochemical properties of camel meat:}

Data in the same Table show the water holding capacity for refrigerator, room temperature, microwave, running water with package and running water without package thawed samples was 73.55 , $68.37,65.69,71.01,72.00 \%$, respectively.

All thawed samples have low WHC than fresh meat sample. These results are in a good agreement with those obtained by Savage et al. (1990) they reported that the loss in WHC is related to the distribution of the muscle fiber as well as the modification and/or denaturation of proteins during freezing and thawing.

In general, there is consensus in the scientific literature in the notion that freezing, frozen storage and thawing contribute to decrease in water holding capacity of meat (Anon and Cavelo, 1980, Nagapo et al., 1999 and Vieira et al., 2009).

The loss of drip ranged from 1.02- $22.95 \%$ the lowest loss was the sample which thawed by microwave, this may be due to the short time for thawing ( $3 \mathrm{~min}$ ). Meanwhile, the highest loss was in the thawed sample by running water with package, this may be due to the long thawing time (12 hrs) and discharge of drip with water. Decrease in thawing time to be low $50 \mathrm{~min}$, resulted in decrease in exudate drip loss. (Anon and Cavelo 1980). There were no changes in $\mathrm{pH}$ value during thawing except the sample thawed at room temperature the $\mathrm{pH}$ decreased from 5.7 to 5.2. This reduction in $\mathrm{pH}$ may be due to deamination of proteins by microbial or enzymatic action causes release of hydrogen atoms, and then decrease $\mathrm{pH}$ (Leygonie et al., 2011). The lower loss in water soluble ash was observed in thawed samples in refrigerator temperature, microwave and room temperature.

\section{Effect of thawing methods microbial count in Libyan camel meat:}

Good hygiene and handling practices are even more important for meat that is to be frozen and thawed compared to that is to be sold fresh (Pham, 2004). Thawed samples by microwave and running water without package had the lower total bacterial count, coliform count, staphylococcus count and yeasts and molds count (Table 2); this may be due to the shorter time for thawing and denaturation of microbial proteins by microwave ray.

Table 2. Effect of thawing methods on microbial count of Libyan camel meat.

\begin{tabular}{|c|c|c|c|c|c|c|}
\hline \multirow[b]{2}{*}{ Microorganisms } & \multirow[b]{2}{*}{$\begin{array}{l}\text { Fresh } \\
\text { meat }\end{array}$} & \multicolumn{5}{|c|}{ Thawing methods } \\
\hline & & $\begin{array}{l}\text { Refrigerator } \\
7^{\circ} \mathrm{C} \\
\text { (For } 12 \text { hrs.) }\end{array}$ & $\begin{array}{l}\text { Room } \\
\text { temperature } \\
\text { (For } 8 \text { hrs.) }\end{array}$ & $\begin{array}{l}\text { Microwave } \\
160 \text { Watt } \\
\text { (For } 3 \mathrm{~min} \text { ) }\end{array}$ & $\begin{array}{l}\text { Running water } \\
\text { with package } \\
\text { at room } \\
\text { temperature } \\
\text { (For } 3 \text { hrs.) }\end{array}$ & $\begin{array}{l}\text { Running water } \\
\text { without } \\
\text { package at } \\
\text { room } \\
\text { temperature } \\
\text { (For } 3 \text { hrs.) }\end{array}$ \\
\hline $\begin{array}{l}\text { Total bacterial } \\
\text { count }\end{array}$ & $1.8 \times 10^{3}$ & $1.5 \times 10^{2}$ & $3.0 \times 10^{5}$ & $8.0 \times 10^{1}$ & $5.5 \times 10^{3}$ & $6.5 \times 10^{1}$ \\
\hline Coliform group & $1.8 \times 10^{2}$ & $1.6 \times 10^{2}$ & $1.2 \times 10^{5}$ & $<10$ & $1.1 \times 10^{3}$ & $<10$ \\
\hline $\begin{array}{l}\text { Staphylococcus } \\
\text { aureus count }\end{array}$ & $2.0 \times 10^{2}$ & $6.5 \times 10^{2}$ & $3.3 \times 10^{4}$ & $1.1 \times 10^{3}$ & $\ll 10$ & $2.3 \times 10^{2}$ \\
\hline $\begin{array}{l}\text { Yeasts and molds } \\
\text { count }\end{array}$ & $1.8 \times 10^{2}$ & $5.5 \times 10^{1}$ & $6.5 \times 10^{1}$ & $<10$ & $3.0 \times 10^{1}$ & $<10$ \\
\hline
\end{tabular}

The thawed sample in running water without package had lower count for total bacterial, Coliform group, Staphylococcus aureus and yeasts and molds, this may be due to microorganisms moved with running water as result microorganisms on the surface of meat diluted. Sample thawed at room temperature and running water with package had the higher counts in total bacterial count, Coliform group and yeasts and molds (Table 2). The drip lost during thawing is rich in proteins vitamins and minerals, provides an excellent medium for microbial growth (Pham, 2004).microbes regain their activity during 
thawing (Löndohl and Nilaaon, 1993). Finally the thawed sample in refrigerator had low counts in total bacterial count, Coliform group, Staphylococcus aureus and yeasts and molds, this may be due to low temperature $\left(6 \pm 1^{\circ} \mathrm{C}\right)$ inhibits the growth of microorganisms.

Effect of cooking methods on WHC and cooking loss for thawed meat in refrigerator and microwave:

Data in Table (3) showed that the all cooking methods decreased the WHC in comparison with fresh meat $(75.88 \%$ Table, 1$)$. It has been reported that, the loss in WHC is related to the distribution of the muscle fiber structure as well as the modification and/or denaturation of proteins during freezing, thawing and cooking (Savage et al., 1990). Sample thawed and cooked by using microwave had the lowest WHC (Table 3). This may be due to denaturation of proteins during microwave cooking. The results are in agreement with those obtained by (Vieira, et al., 2009). They reported that during cooking, the melting of fat and denaturation of proteins reportedly cause the release of chemically bond water. Sample thawed at refrigerator temperature, then cooked in pan under pressure had the highest WHC 64.52\%. This result is in a good agreement with those stated by (Taher, 1983 and Elgalily et al., 1985). The high value in WHC for thawed sample in refrigerator, then cooked in pan under pressure may be due to hydrolysis the connective tissue (collagen) to gelatin at temperature more than $100^{\circ} \mathrm{C}$ as result the WHC increased. On the other hand, there is no big difference in cooking loss percent between cooking methods, it ranged from 26.25 to $34.12 \%$.

Effect of cooking methods on chemical composition of camel meat which thawed at refrigerator temperature and microwave methods:

Data in Table (4) indicated that, the thawed sample at refrigerator temperature then cooked by different cooking methods had the same trend for thawed sample in microwave then cooked by different cooking methods in protein, crude fat and ash content. Thawed samples at refrigerator temperature then cooked by different method usually had the higher value of moisture and proteins than that thawed in microwave then cooked by different cooking methods.

\section{Effect of cooking methods on chemical composition of camel meat thawed in microwave:}

Data in the same Table observed that the all cooking methods decreased the moisture content for cooked meat in comparison with fresh or thawed meat. Thawed sample then cooked in microwave had the lower moisture content; this is due to denaturation of proteins and evaporation of water inside microwave. Cooking in microwave increased total ash and inhibit loss of water soluble ash, meanwhile blanch cooking (wet cooking) decreased the total and water soluble ash as result of moving minerals to blanching water. The proteins content for cooked samples increased in comparison with thawed or fresh meat, this may be due to loss of water and increased of the dry matter in meat proportionally. The sample cooked in pan under pressure had the lowest total fat because high temperature melts the fat, then it moved to blanching water.

Effect of cooking methods on sensory evaluation of camel meat thawed at refrigerator temperature and microwave methods:

Data in Table (5) showed that, there was no effect of cooking methods on flavor, color and appearance of cooked camel meat (Table 5). Statistical analysis indicates that there was no significant difference among cooking methods. Samples cooked in microwave had lower juiciness and tenderness than that cooked by wet cooking (blanching). These results are in excellent agreement with results of WHC thawing microwave or cooking decreased the juiciness of meat. Cooking in pan under pressure enhance the texture of camel meat. This may be due to hydrolysis of connective tissue and melting of fat inside tissues then prevent loss of water. The higher score for overall acceptability was for thawed sample in microwave and cooked by blanching (88.2) the best texture was for thawed sample in microwave then cooked in pan under pressure which had value (22.6).

Table 3. Effect of cooking methods on water holding capacity and cooking loss of Libyan camel meats thawed by microwave and refrigerator methods.

\begin{tabular}{lcccccc}
\hline \multirow{2}{*}{ Properties } & \multicolumn{2}{c}{ Microwave thawing (160 Watt) } & \multicolumn{2}{c}{ Refrigerator thawing $\left(6 \pm 1^{\circ} \mathrm{C}\right)$} \\
\cline { 2 - 7 } & $\begin{array}{c}\text { Blanching* } \\
\text { cooking }\end{array}$ & $\begin{array}{c}\text { Microwave } \\
\text { cooking }\end{array}$ & $\begin{array}{c}\text { Pressure } \\
\text { pan } \\
\text { cooking }\end{array}$ & $\begin{array}{c}\text { Blanching* } \\
\text { cooking }\end{array}$ & $\begin{array}{c}\text { Microwave } \\
\text { cooking }\end{array}$ & $\begin{array}{c}\text { Pressure } \\
\text { cooker } \\
\text { cooking }\end{array}$ \\
\hline WHC \% & 53.65 & 51.7 & 63.44 & 63.09 & 53.44 & 64.52 \\
\hline Cooking loss \% & 26.35 & 33.25 & 26.25 & 29.75 & 34.12 & 28.00 \\
\hline
\end{tabular}

* wet cooking under atmospheric pressure. 
Table 4. Effect of cooking methods on chemical composition of Libyan camel meat which thawed by microwave and refrigerator methods.

\begin{tabular}{lcccccc}
\hline Component & \multicolumn{2}{c}{ Microwave thawing camel meat } & \multicolumn{2}{c}{ Refrigerator thawing camel meat } \\
\cline { 2 - 7 } & $\begin{array}{c}\text { Blanching } \\
\text { cooking }\end{array}$ & $\begin{array}{c}\text { Microwave } \\
\text { cooking }\end{array}$ & $\begin{array}{c}\text { Pressure } \\
\text { cooker } \\
\text { cooking }\end{array}$ & $\begin{array}{c}\text { Blanching } \\
\text { cooking }\end{array}$ & $\begin{array}{c}\text { Microwave } \\
\text { cooking }\end{array}$ & $\begin{array}{c}\text { Pressure } \\
\text { cooker } \\
\text { cooking }\end{array}$ \\
\hline Moisture \% & 53.65 & 51.71 & 63.44 & 63.09 & 53.44 & 64.52 \\
\hline Protein \% & 26.35 & 33.25 & 26.25 & 29.75 & 34.12 & 28.00 \\
\hline Crude fat \% & 14.29 & 13.93 & 4.01 & 14.29 & 12.93 & 4.91 \\
\hline Soluble ash \% & 0.13 & 0.95 & 0.30 & 0.20 & 0.87 & 0.23 \\
\hline Insoluble ash \% & 0.38 & 0.52 & 0.25 & 0.31 & 0.29 & 0.18 \\
\hline
\end{tabular}

Table 5. Effect of cooking methods on sensory evaluation of Libyan camel meat.

\begin{tabular}{|c|c|c|c|c|c|c|c|}
\hline \multirow[b]{2}{*}{$\begin{array}{l}\text { Thawing } \\
\text { methods }\end{array}$} & \multirow[b]{2}{*}{ Cooking methods } & \multicolumn{5}{|c|}{ Means } & \multirow{2}{*}{$\begin{array}{c}\text { Total } \\
\text { acceptability } \\
(100)\end{array}$} \\
\hline & & $\begin{array}{c}\text { Flavor } \\
(25)\end{array}$ & $\begin{array}{l}\text { Texture } \\
\text { (25) }\end{array}$ & $\begin{array}{l}\text { Color } \\
\text { (20) }\end{array}$ & $\begin{array}{l}\text { Juiciness } \\
\text { (20) }\end{array}$ & $\begin{array}{c}\text { Appearance } \\
(10)\end{array}$ & \\
\hline \multirow{3}{*}{ Microwave } & Blanching & 22 & $21.8^{\mathrm{ab}}$ & 17.2 & $19.0^{\mathrm{a}}$ & 8.2 & $88.2^{\mathrm{a}}$ \\
\hline & Microwave & 19 & $18.0^{\mathrm{c}}$ & 18.2 & $13.8^{\mathrm{c}}$ & 7.6 & $76.4^{b}$ \\
\hline & Pressure cooker & 21.8 & $22.6^{\mathrm{a}}$ & 17.4 & $18.0^{\mathrm{ab}}$ & 7.6 & $87.4^{\mathrm{a}}$ \\
\hline \multirow{3}{*}{$\begin{array}{l}\text { Refrigerator } \\
\text { at }\left(6 \pm 1^{\circ} \mathrm{C}\right)\end{array}$} & Blanching & 20.8 & $20.0^{\mathrm{ab}}$ & 16.8 & $18.2^{\mathrm{ab}}$ & 7.4 & $83.2^{\mathrm{a}}$ \\
\hline & Microwave & 18.8 & $18.2^{\mathrm{c}}$ & 17.0 & $15.8^{\mathrm{bc}}$ & 7.0 & $76.8^{b}$ \\
\hline & Pressure cooker & 21 & $19.6^{\mathrm{bc}}$ & 17.8 & $17.4^{\mathrm{ab}}$ & 8.2 & $84.0^{\mathrm{a}}$ \\
\hline L.S.D ${ }_{0.05}$ & & - & 2.58 & - & 2.58 & - & 6.29 \\
\hline
\end{tabular}

Means designed with the same letter within each column are not significantly different

(-) LSD was not calculated because; there are no significant differences in the analysis of variance table .

\section{References}

A.O.A.C. (2005). Official Methods of Analysis. Of A.O.A.C. International. $18^{\text {th }}$ ed. Gaithershburg, Maryland, USA.

Abdallah, M.F. (1999).Studies on meat production from camels. Ph.D. Thesis, Cairo Univ., Egypt.

Añón, M.C. and Cavelo, A. (1980): Freezing rate effects on the drip loss of frozen beef. Meat Science, 4: 1-14.

APHA (1992): Compendium of methods for microbiological examination of food Inc. American Public Health Association Washington DC.

Babiker, S.S. and Yousif, O.K. (1990): Chemical composition \& quality of camel meat. Meat Science, 27: 283-287.

Dawood, A.A. and Alkanhal, M.A. (1995): Nutrient composition of Najdi camel meat. Meat Science, 39(1): 71-78.

Durate, M.S.; Paulino, P.V.R.; Fonseca, M.A.; Diniz,L.I.; Cavali, J.; Serão, N.V.L.; Gomide, L.A.M.; Reis, S.F. and Cox, R.B. (2011): Influence of dental carcass maturity on carcass traits and meat quality of Nellore bulls. Meat Science, 88: 441-446.

El-Faer, M.Z.; Radwah, T.N.; Attar, K.M. and Dawson, M.V. (1991): Mineral and approximate composition of the meat of the one humped camel (camelus dromedaries). Food Chemistry, 42(2): 139-143.
Elgalili, F.Z; said, A. and Aziz, L.S. (1985): Production and Preservation of meat. Ministry of Higher Education Research, Emosal press, Iraq.

Leygonie, C.; Britz, T.J. and Hoffman, L.C. (2011): Oxidative stability of previously frozen ostrich M.iliofibularis packaged under different modified atmospheric conditions. Inter. J. of Food Sci. and Technol., 46: 1171-1178.

Leygoine, C.; Britz, T.J, and Hoffman, L.C. (2012): Meat quality comparison between fresh and frozen/thawed Ostrich M.iliofibularis. Meat Science, 91: 364-368.

Löndhal,G. and Nilaaon, T.(1993): Storage of frozen foods. In B. Caballero (Ed.), Encyclopedia of food science and nutrition (pp. $2732-2735) .\left(2^{\text {nd }}\right.$ Ed.). Oxford: Academic Press.

Ngabo, T.M.; Babare, I.H., Reyounolds, J. and Mawson, R.F. (1999): Freezing and thawing rate effects on drip loss from samples of pork. Meat Science, 53: 149-158.

Patsias, A.; Badeka, A.V.; Savvaidis, I.N. and Kontominas, M.G. (2008): Combined effect of freeze chilling and MAP on quality parameters of raw chicken fillets. Food Microbiology, 25: 575581.

Pham, Q.T. (2004): Thawing in Jensen (Ed.), Encyclopedia in meat science, vol.3.(pp. 11501156). Oxford: Elsevier Academic Press.

Savage,A.W.; Warris, P.D.; and Jolley, P.D. (1990): The amount and composition of the proteins in drip from stored pig meat. Meat Science, 27: 289303. 
Sheriha, M.A. (2000): Camels in Arabic countries breading and production. Tripoli University Printing and Publishing Management, Tripoli, Libya.

Sherstha, S.; Schaffner, D. and Nummer, B.A. (2009): Sensory Quality and food safety of boneless chicken breast portion thawed rapidly by submersion in hot water., Food Control, 20: 706-708.
Snedecor, G.W. and Cochran, W.G. (1980): Statistical methods $17^{\text {th }}$ ed. The lowa state Univ. Press Ames. Lowa. USA.

Taher, A.M. (1983): Principles of Meat Science. Elbasra University Press, Iraq.

Vieira, C.; Diaz, M.Y.; Martinez, B. and GarcíaCachán, M.D. (2009): Effect of frozen storage conditions (temperature and length of storage) on microbial and sensory quality of rustic crossbred beef at different stages of aging. Meat Science, 83: 398-404.

\section{تأثير طرق فلك التجميد والطهي علي جودة لحوم الابل الليبية}

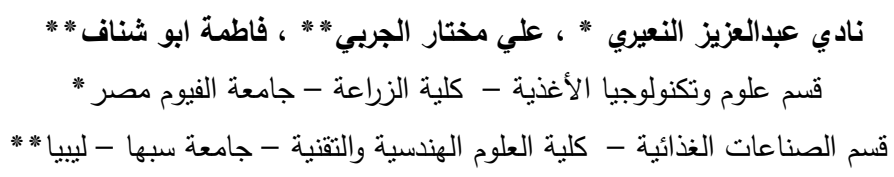

تم دراسة تأثير طرق فلك التجميد وطرق الطهي على التزكيب الكيميائي والجودة الحسية للحوم الابل الليبية. جهزت العينات ووضعت في عبوات

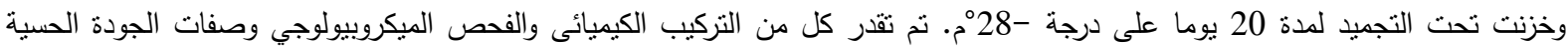

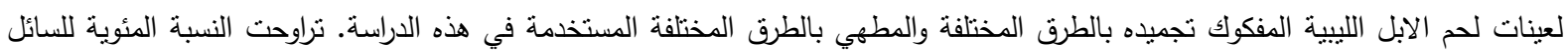

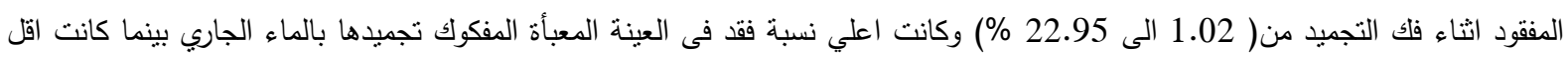
نسبة فقد فى العينة الدفكوك تجميدها باستخدام فرن الميكروويف .جميع طرق فلك التجميد والطهي. أدت الى انخفاض مقدرة اللحم على مسك

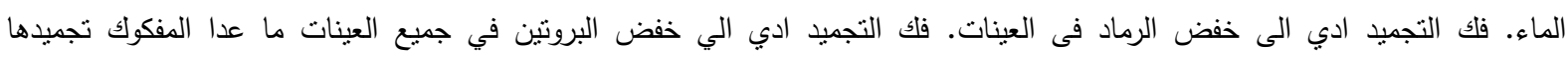

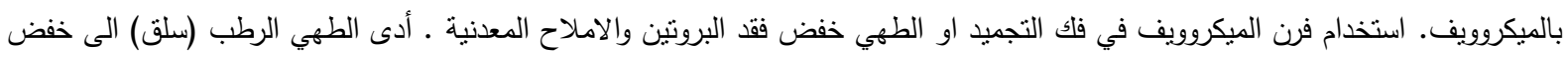

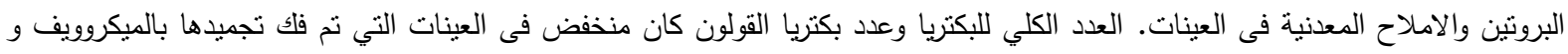

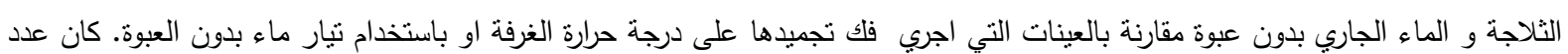

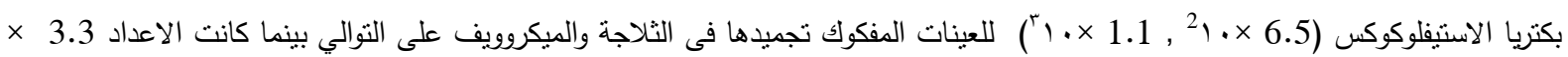

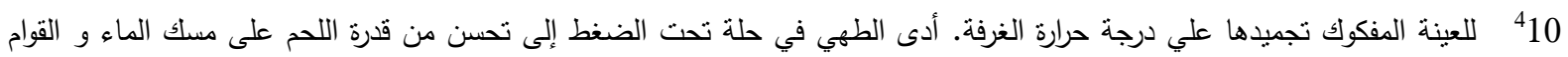

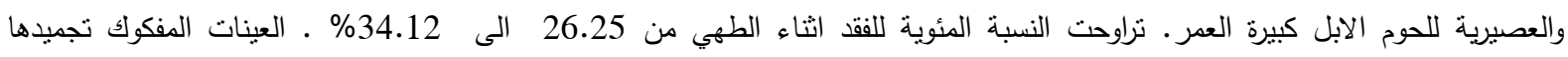

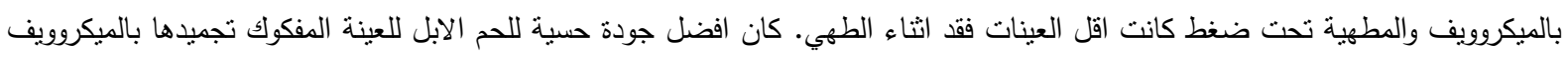
ثم الطهي باستخدام حلة الضغط يليها المفكوك تجميدها في الثلاجة والمطهية في حلة تحت ضغنط. 